UDC 614.71: 612.017.1-053.6

DOI: $10.21668 /$ health.risk/2020.2.12.eng

\title{
INFLUENCE EXERTED BY INHALATION BURDEN WITH FORMALDEHYDE ON CYTOKINES IEVEL IN TEENAGERS LIVING IN INDUSTRIAL CENTERS
}

\author{
L.B. Masnavieva, I.V. Kudaeva \\ East-Siberian Institute of Medical and Ecological Research, 12 a the 3rd micro-district, Angarsk, 665827, \\ Russian Federation
}

The atmospheric air is polluted with formaldehyde and it exerts negative influence on population health; first of all, the immune system suffers as it is the most sensitive to impacts exerted by environmental factors. Our research goal was to examine levels of specific auto-antibodies and cytokines in teenagers depending on an individual inhalation burden with formaldehyde. We calculated a personified hazard index of inhalation exposure to formaldehyde for each school student. A formula for its calculation included data on air pollution with formaldehyde inside school rooms and teenagers' homes, the atmospheric air pollution, anthropometric and spirometry data, as well as data on school students' daily regime. We examined cytokines and specific auto-antibodies in blood serum of teenagers as these two parameters reflected the immune system state. We revealed correlations between a hazard quotient for exposure to formaldehyde and contents of auto-antibodies to $\beta_{2}$-glycoprotein I and to Fc-fragment of IgG, levels of interleukin-2, alpha- and gamma-interferon. We also detected that a share of people with elevated immune reactivity of auto-antibodies to $\beta_{2}$-glycoprotein I and to Fc-fragment of IgG increased as the hazard quotient for exposure to formaldehyde grew. Correlations between the examined parameters of the immune system grew in their strength and number and it proved that pro- and anti-inflammatory processes became more conjugated under inhalation exposure to formaldehyde that was higher than the reference level. Teenagers with their hazard quotient for exposure to formaldehyde was higher than 1 tended to have lower concentrations of interleukin-2, alpha- and gammainterferons, and there was strain in their system of pro- and anti-inflammatory processes as inhalation burden with formaldehyde became greater.

Key words: air pollution, inhalation load, formaldehyde, adolescents, the immune system, interleukins, interferons, autoantibodies.

Air pollution makes a significant contribution into health risks for people who live in large industrial cities [1, 2]. Emissions from chemical and oil-processing enterprises contain aromatic hydrocarbons, hydrogen sulfide, sulfur and nitrogen dioxides, carbon dioxide. Increased air pollution caused by industrial emission can lead to occurrence of pathologies in organs that are target ones for impacts exerted by pollutants [3-5]. It is well known that when formaldehyde, benzpyrene, phenol, or nitrogen dioxide penetrate a body, it influences the immune system $[3,6,7]$, and changes in its activity become apparent via modifications of cytokines synthesis by immune-competent cells. Air pollutants produce their effects on intensity of cell renewal and it can also cause changes in production of auto-anti-bodies (auto-AT) which are known to participate in apoptotic cells clearance.

Our research goal was to examine contents of cytokines and specific auto-anti-bodies in teenagers depending on an individual burden with formaldehyde.

Data and methods. At the initial stage of our research we questioned parents (legal representatives) of 1,150 teenagers aged 11-17 who lived in industrial cities and in rural areas of Irkutsk region. After parents (legal representatives) of 805 children gave their written informative consent, the teenagers were examined by medical experts, and data from their case histories were analyzed. 561 teenagers conformed to all the criteria to be included into

(c) Masnavieva L.B., Kudaeva I.V., 2020

Lyudmila B. Masnavieva - Candidate of Biological Sciences, senior researcher at the laboratory for immunological, biochemical, molecular and genetic research in hygiene (e-mail: Masnavieva_Luda@mail.ru, tel.: +7 (964) 657-11-62; ORCID: http://orcid.org/ 0000-0002-1400-6345).

Irina V. Kudaeva - Associate Professor, Deputy Director for Research, Head of the clinical and diagnostic laboratory (e-mail: Kudaeva_Irina@mail.ru; tel.: +7 (914) 003-19-76; ORCID: http://orcid.org/0000-0002-5608-0818). 
the in-depth research. They belonged to the 1st and 2 nd health groups (in other words, they had some minor health disorders or none at all and didn't have any chronic pathologies); they permanently lived and studied at educational organizations on the examined territories; they didn't have any signs of respiratory diseases and exacerbations of somatic pathologies during the examination period and 2 weeks prior to it.

An individual chemical burden on teenagers' bodies was estimated on the basis of data on admixture concentrations in the atmospheric air, and indoor concentrations of priority pollutants (both at home and in an educational organization). We introduced personified data on each school students into a formula for calculating a dose chemical inhalation burden; such data included anthropometric and spirometry parameters, and information about a daily regime. Hazard quotients (HQ) for inhalation exposure to formaldehyde were calculated in accordance with the Human health risks assessment from environmental chemicals [8] taking into account personified data on each individual ${ }^{1}$ [9]. Teenagers were divided into two groups according to obtained HQ for exposure to formaldehyde. The first group was made up of 227 school students with HQ lower than 1; the second group was made up of 423 teenagers with HQ equal to 1 or higher. $41.2 \%$ teenagers in the first group were boys (average age was equal to $14.31 \pm 0.12$ ), $58.8 \%$ teenagers were girls (average age was equal to $14.79 \pm 0.09$ ). The second group was made up of $47.3 \%$ boys and $52.7 \%$ girls (average age was equal to $14.66 \pm 0.12$ and $15.01 \pm 0.10$ respectively).

Blood samples were taken from teenagers in the morning on empty stomach. We examined cytokines concentrations in blood serum, namely interleukins- 2 and -10 , alpha- and gamma-interferons (IL-2, IL-10, INF- $\alpha$, and INF- $\gamma$ respectively). Cytokines concentrations were determined via ELISA tests with relevant test-systems («Vector-Best», Novosibirsk).
Reference concentrations for IL-2 and IL-10 amounted to $0-10 \mathrm{pg} / \mathrm{ml}$; for INF- $\alpha$ and INF- $\gamma$, up to 5 and $15 \mathrm{pg} / \mathrm{ml}$ respectively.

We also determined relative concentrations of auto-AT to native DNA (nDNA), Fc-fragment of IgG, and beta2-glycoprotein $(\beta 2-\Gamma \Pi \mathrm{I})$ in teenagers' blood serum as these parameters reflect the immune system state. To determine anti-bodies concentrations with ELISA technique, we applied ELI-VisceroTest-16 test-systems («Immunkulus», Moscow). A range from -20 up to $+10 \%$ is a reference concentration for relative contents of specific auto-AT within the above-mentioned test-system.

We analyzed the results statistically with «Statistica 6.0» applied software and applied such non-parametric tests as Mann-Whitney U-criterion and Spearman rank correlation (r). The research results are given as a median and 25-75 quartiles (Me (LQ-UQ)). We detected discrepancies between groups as regards frequency of elevated values for the examined parameters with a technique for assessing prevalence of a sign in a sampling. A $p$ value equal to 0.05 was considered to be a critical statistical significance of discrepancies.

Results and discussion. Having assessed atmospheric air quality and air quality inside teenagers' homes and classrooms on the examined territories, we detected formaldehyde, particular matter, and nitrogen dioxide in concentrations which were higher than reference ones. Average annual PM concentration in the atmosphere varied from 0.012 to $0.142 \mathrm{mg} / \mathrm{m}^{3}$; it was within $0.026-0.172 \mathrm{mg} / \mathrm{m}^{3}$ and $0.033-0.135 \mathrm{mg} / \mathrm{m}^{3}$ in the air inside homes and classrooms respectively (reference concentration is equal to $\left.0.075 \mathrm{mg} / \mathrm{m}^{3}\right)$. The same ranges for nitrogen dioxide and sulfur dioxide respectively amounted to $0.007-0.062 \mathrm{mg} / \mathrm{m}^{3}$ and $0.0004-0.038 \mathrm{mg} / \mathrm{m}^{3}$ in the atmospheric air; $0.007-0.030 \mathrm{mg} / \mathrm{m}^{3}$ and $0.0001-0.033 \mathrm{mg} / \mathrm{m}^{3}$ in the air inside homes; and $0.008-0.044 \mathrm{mg} / \mathrm{m}^{3}$ and $0.002-0.018 \mathrm{mg} / \mathrm{m}^{3}$, in the air inside class-

${ }^{1}$ G 2.1.10.1920-04. Guidelines for assessing the risk to public health when exposed to chemicals that pollute the environment. Moscow, Federal Center for State Sanitary and Epidemiological Supervision of the Ministry of Health of Russia, 2004, 143 p. (in Russian). 
rooms (reference concentrations for these compounds amount to 0.04 and $0.05 \mathrm{mg} / \mathrm{m}^{3}$ ). Average annual concentrations of carbon oxide and formaldehyde respectively amounted to $0.11-2.34 \mathrm{mg} / \mathrm{m}^{3}$ and $0.000-0.006 \mathrm{mg} / \mathrm{m}^{3}$ in the atmospheric air; $0.563-0.678 \mathrm{mg} / \mathrm{m}^{3}$ and $0.0014-0.0066 \mathrm{mg} / \mathrm{m}^{3}$, in the air inside homes; $0.073-0.340 \mathrm{mg} / \mathrm{m}^{3}$ and $0.000-0.006 \mathrm{mg} / \mathrm{m}^{3}$, in the air inside classrooms. Reference concentrations for carbon oxide and formaldehyde are 3.0 and $0.003 \mathrm{mg} / \mathrm{m}^{3}$ respectively.

As per data obtained via the questioning, teenagers spend from 20 to 23 hours a day at home and at school; therefore, indoor air pollution contributes significantly into an individual chemical burden and HQ for exposure to pollutants. Exposure to formaldehyde made the greatest contribution into a risk of immune disorders as personified HQ for this chemical ranged from 0.60 to 2.03 for the examined teenagers (average value was equal to $1.35 \pm 0.02)$. These elevated hazard quotients for exposure to formaldehyde are caused by the substance penetrating the air inside homes or classrooms out of furniture, construction and finishing materials [10], and the atmospheric air, due to emissions from industrial enterprises [3, 5].

We detected lower average IL-2 concentrations in teenagers from the second group than in those from the first one (Table 1). Since this interleukin determines duration and type of an immune response and participates in regulating IFN- $\gamma$ contents stimulating its synthesis [11], a decrease in IL-2 concentration can lead to changes in gamma-interferon contents; it is confirmed by lower IFN- $\gamma$ contents which we detected in the second group. The 1st type T-helpers (Th1) are known to produce IL-2 and IFN- $\gamma$; therefore, lower concentrations of these cytokines in school students from the second group can indirectly imply that Th1 are less active in them. We detected significantly lower constitutive concentrations of INF- $\alpha$ (10 times lower) that had antiviral activity in teenagers from the group with $\mathrm{HQ} \geq 1$. Given all that, we can assume that teenagers with inhalation exposure to formaldehyde within reference concentrations have signs of inflammatory reactions; when teenagers are exposed to higher concentrations of this toxicant, they run significantly greater risks of inflammatory diseases becoming chronic.

This assumption was also confirmed by our analysis of auto-AT contents in groups with different inhalation burden with formaldehyde. High concentration of specific autoAT is known to be a sign that disorders are occurring in organs and systems and they, among other things, can be caused by bacterial and viral infections and can occur long before any clinical manifestations of a diseases become visible [12]. Elevated concentrations of auto-AT to nDNA were detected in the second group less frequently than in the first group (31.8 and $20.7 \%$ respectively, $p<0.005$ ). A share of people with hyper immune reactivity of auto-AT to Fc-fragment of $\mathrm{IgG}$ and to $\beta 2-G P$ I was 4.5 times and 9 times higher among those with $\mathrm{HQ} \geq 1(32 \%, p<0.005$;

Table 1

Cytokines and auto-anti-bodies concentrations in teenagers under inhalation exposure to formaldehyde, Me (LQ-UQ)

\begin{tabular}{|l|c|c|c|}
\hline \multicolumn{1}{|c|}{ Parameters, units } & Group I & Group II & $p$ \\
\hline IL-2, $\mathrm{pg} / \mathrm{ml}$ & $4.51(1.56-7.25)$ & $2.71(0.01-5.38)$ & 0.000 \\
\hline IL-10, pg/ml & $3.42(0.7-6.76)$ & $3.39(1.40-6.44)$ & 0.713 \\
\hline INF- $\alpha, \mathrm{pg} / \mathrm{ml}$ & $3.76(1.43-14.13)$ & $0.36(0.01-4.87)$ & 0.000 \\
\hline INF- $\gamma, \mathrm{pg} / \mathrm{ml}$ & $5.91(4.23-8.32)$ & $2.81(1.89-4.89)$ & 0.000 \\
\hline Auto-AT to nDNA, \% & $4.64(-6.27-20.59)$ & $0.93(-10.54-11.48)$ & 0.003 \\
\hline Auto-AT to $\beta 2-G P I, \%$ & $-19.83(-29.08--11.75)$ & $-1.56(-14.55-11.09)$ & 0.000 \\
\hline Auto-AT to Fc-fragment of IgG, \% & $-7.57(-13.70-1.87)$ & $3.97(-8.25-12.68)$ & 0.000 \\
\hline
\end{tabular}

$\mathrm{N}$ o t e: $p$ means a level when discrepancies become statistically significant. 
$28 \%, p<0.005$ respectively) than in the first group ( $7 \%$ and $3 \%$ respectively). It proves that infectious and inflammatory processes occurred in teenagers from the second group more frequently than in those from the first one since it is well known that elevated concentrations of auto-AT to DNA and beta-2glycoprotein 1 indicate there is cell apoptosis in a body which is most frequently induced by an active bacterial or a viral infection, and auto-AT to Fc-fragments of immune globulins reflect protective responses of the immune system aimed at limiting inflammatory processes activity [12]. We should note that previous research revealed an increase in auto-AT contents in children who lived on territories with average atmospheric air contamination; those auto-AT characterized a specific state of the immune system that occurred when inflammatory processes caused by infections were developing in a body; children who lived on territories with significant air contamination ran elevated risks of pathologies in the immune system and their auto-AT had weaker immune reactivity [13].

We analyzed relative auto-AT concentrations depending on personified chemical burden with formaldehyde and revealed that a concentration of auto-AT to $\beta 2-\mathrm{GP}$ I and to Fc-fragment of IgG was statistically significantly higher in the second group, and that of auto-AST to nDNA, in the first one. It indicates that weaker resistance of a body to infectious agents in teenagers who lived on environmentally adverse territories was primarily caused by total inhalation burden with formaldehyde coming from both the atmospheric air and the air inside homes or classrooms.
A contribution made by formaldehyde into changes that occur in the humoral immunity parameters in teenagers is confirmed by correlations between chemical burden with the pollutant and cytokines and auto-anti-bodies concentrations (Table 2). We detected that exposure to formaldehyde led to a decrease in concentrations of IL- 2 , INF- $\gamma$, and INF- $\alpha$, and an increase in concentrations of auto-AT to $\beta 2-G P$ I and to Fc-fragment of IgG.

We should note that correlations detected for the overall examined sampling were characteristic for the teenagers group with $\mathrm{HQ} \geq 1$ (Table 2), excluding the correlation between HQ and concentration of auto-AT to Fc-fragment of IgG. This particular correlation was detected in the overall sampling $(R=0.32$, $p<0.001)$, but it was absent when the first and the second group were considered separately. The fact that there is no correlation between IL-10 concentration and chemical burden with formaldehyde indicates that elevated concentrations of this cytokine in teenagers from the second group are not directly caused by exposure to formaldehyde but they rather result from changes that occur in the immune system at this age.

As we examined correlations between the examined parameters of the immune system, we revealed that a number of these correlations and their strength were higher among teenagers with greater inhalation burden with formaldehyde (the second group) than among those from the first group (Table 3); the nature of these correlations indicated that there was strain in the system of pro- and anti-inflammatory processes. Thus, if we take a correlation between IL-2 and INF- $\gamma$ concentrations,

Table 2

Correlations between hazard quotients for exposure to formaldehyde, cytokines and auto-anti-bodies concentrations in teenagers

\begin{tabular}{|l|c|c|c|c|c|c|}
\hline \multirow{2}{*}{ Parameters } & \multicolumn{2}{c|}{ Overall sampling } & \multicolumn{2}{c|}{ Group I } & \multicolumn{2}{c|}{ Group II } \\
\cline { 2 - 7 } & $\mathrm{R}$ & $\mathrm{p}$ & $\mathrm{R}$ & $\mathrm{p}$ & $\mathrm{R}$ & $\mathrm{p}$ \\
\hline HQ \& auto-AT to $\beta 2-$ GP I & 0.44 & 0.001 & -0.04 & 0.500 & 0.17 & 0.010 \\
\hline HQ \& IL-2 & -0.30 & 0.001 & 0.06 & 0.397 & -0.25 & 0.001 \\
\hline HQ \& INF- $\alpha$ & -0.37 & 0.001 & 0.09 & 0.210 & -0.28 & 0.001 \\
\hline HQ \& INF- $\gamma$ & -0.45 & 0.001 & -0.01 & 0.902 & -0.12 & 0.036 \\
\hline
\end{tabular}

$\mathrm{N}$ o t e: R is correlation quotient, $\mathrm{p}$ means a level when discrepancies become statistically significant. 
Table 3

Correlations between cytokines concentrations in teenagers depending on inhalation exposure to formaldehyde

\begin{tabular}{|l|c|c|c|c|}
\hline \multirow{2}{*}{\multicolumn{1}{|c|}{ Parameters }} & \multicolumn{2}{c|}{ Group I } & \multicolumn{2}{c|}{ Group II } \\
\cline { 2 - 5 } & $\mathrm{R}$ & $\mathrm{p}$ & $\mathrm{R}$ & $\mathrm{p}$ \\
\hline IL-2\&INF- $\gamma$ & -0.06 & 0.400 & 0.39 & 0.0001 \\
\hline IL-2\&IL-10 & 0.17 & 0.025 & 0.44 & 0.0001 \\
\hline IL-2\&INF- $\alpha$ & -0.31 & 0.0001 & 0.62 & 0.0001 \\
\hline INF- $\gamma$ \&INF- $\alpha$ & -0.03 & 0.700 & 0.51 & 0.0001 \\
\hline IL-10 \&INF- $\alpha$ & 0.13 & 0.070 & 0.40 & 0.0001 \\
\hline
\end{tabular}

$\mathrm{N}$ o t e: $\mathrm{R}$ is correlation quotient, $\mathrm{p}$ means a level when discrepancies become statistically significant.

we can note that the 1 st type T-helpers increase IL-2 production that stimulates functional activation of $\mathrm{T}$ - and B-lymphocytes, NK-cells and monocytes, and these cells play a significant role in protective responses of a body [14]. Since IL-2 synthesis is inducible one, regulation of IL-2-dependent lymphocytes proliferation directly depends on a specific antigen occurrence $[15,16]$.

INF- $\gamma$ also has regulatory functions related to the immune systems cells; it is synthesized in a body mostly by antigens-activated T-lymphocytes (primarily Th1) and NK-cells. It activates macrophages and enhances activities of the cell-mediated immunity and plays a significant role in Th1-lymphocytes differentiation acting according to a positive feedback principle [17]. Correlations between IL-2 and INF- $\gamma$ concentrations prove that such processes occur in bodies of teenagers with higher inhalation burden with formaldehyde. Besides, INF- $\gamma$, together with IL-2, is able to control activation of the cell-mediated immunity with T-regulatory lymphocytes participation [18].

IL-10 also performs an immune-regulatory function as regards immune response suppression due to its participation in regulating and performing effector functions of T-regulatory lymphocytes. This interleukin is basically synthesized by such cells as activated CD4+, CD8+, T-lymphocytes, B-lymphocytes, LPS-activated monocytes/macrophages, and Th1. IL-10 negatively regulates synthesis of IL-2, INF- $\gamma$, anti-inflammatory cytokines, antigen-representing function of macrophages and dendritic cells as well as switches an im- mune response from a Th1-depending type to a Th2-depending one $[19,20]$. A correlation between IL-2 and Il-10 which we revealed in our research together with lower IL-2 and INF- $\gamma$ concentrations in children from the second group against those from the first group and with comparable IL-10 concentrations in both groups is an evidence that mechanisms of anti-inflammatory immune response regulation are deregulated. Besides, when IL-10 excessively suppresses production of Il-2 and INF- $\gamma$ in teenagers with $\mathrm{HQ} \geq 1$, it can lead to occurrence of susceptibility to allergy, including ecological pollutants allergy. In particular, some previous research revealed that examined children with sensitization to formaldehyde had higher IL-10 concentration in swabs taken from their oral cavity than people who didn't have any reaction to this allergen [21]. Regulatory strain in Th1 lymphocytes system in school students with higher inhalation burden with formaldehyde is also borne out by positive correlation between INF- $\alpha$ concentration and concentrations of cytokines (IL-2, INF- $\gamma$ ) that support differentiation of $\mathrm{T}$ lymphocytes into Th1 population.

All the obtained results helped us to create a scheme that reflects influence exerted by inhalation exposure to formaldehyde on cytokines concentrations in teenagers' blood (Figure).

Conclusion. Overall, we detected that occurrence of formaldehyde in the atmospheric air and in air inside homes or classrooms in concentrations higher than reference ones caused elevated risks of pathologies in teenagers' immune system. Personified hazard 


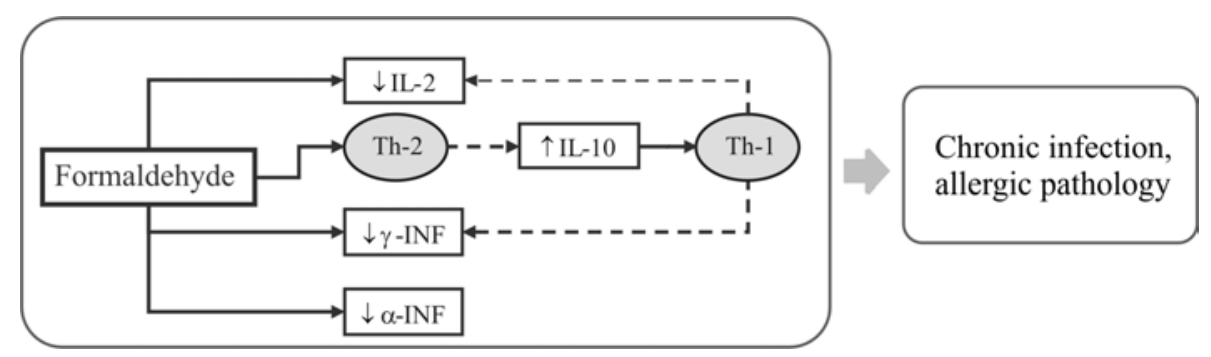

Figure. Influence exerted by inhalation exposure to formaldehyde on cytokines concentrations in teenagers

quotients for exposure to formaldehyde for teenagers living in industrial centers reached 2.03. We revealed that a growth in inhalation burden with formaldehyde was accompanied with more frequent increase in concentrations of specific auto-anti-bodies to $\beta 2$-GP I and to Fc-fragment of $\operatorname{IgG}$ which were signs that pathological processes caused by bacterial and viral agents were developing in organs and systems. When a hazard quotient for exposure to formaldehyde exceeded 1 , INF- $\alpha$, INF- $\gamma$, and IL-2 concentrations went down, and strain in the system of pro-and anti-inflammatory processes occurred.

Funding. The work has been accomplished due to financial support provided for completing tasks set by the Government and funds belonging to the East-Siberian Institute for Medical and Ecological Research.

Conflict of interests. There are no apparent or potential conflicts of interests related to publication of the present paper.

\section{References}

1. Vyalkov A.I., Bobrovnitskii I.P., Rakhmanin Yu.A., Razumov A.N. Puti sovershenstvovaniya organizatsii zdravookhraneniya $\mathrm{v}$ usloviyakh rastushchikh ekologicheskikh vyzovov bezopasnosti zhizni i zdorov'yu naseleniya [Ways of improving the health organization in the conditions of growing ecological challenges of life safety and population health]. Russian Journal of Rehabilitation Medicine, 2017, no. 1, pp. 24-41 (in Russian).

2. Trifonova T.A., Martsev A.A. Otsenka vliyaniya zagryazneniya atmosfernogo vozdukha na zabolevaemost' naseleniya Vladimirskoi oblasti [Assessing the impact of air pollution on public health Vladimir region]. Gigiena i sanitariya, 2015, vol. 94, no. 4, pp. 14-18 (in Russian).

3. Zaitseva N.V., Dolgikh O.V., Dianova D.G. Vliyanie kontaminatsii formal'degidom na pokazateli immunnoi sistemy u detei [Formaldehyde contamination influence on immune system in children]. Izvestiya Samarskogo nauchnogo tsentra Rossiiskoi akademii nauk. Sotsial'nye, gumanitarnye, medikobiologicheskie nauki, 2014, vol. 16, no. 5-2, pp. 702-704 (in Russian).

4. Urman R., McConnell R., Islam T., Avol E.L., Lurmann F.W., Vora H., Linn W.S., Rappaport E.B. [et al.]. Associations of children's lung function with ambient air pollution: joint effects of regional and near-roadway pollutants. Thorax, 2014, vol. 69, no. 6, pp. 540-547. DOI: 10.1136/thoraxjnl-2012-203159

5. Askarov R.A., Askarova Z.F., Karelin A.O. Otsenka dinamiki zagryazneniya atmosfernogo vozdukha ot statsionarnykh istochnikov $\mathrm{v}$ regionakh respubliki Bashkortostan [The evaluation of dynamics of pollution of atmospheric air by stationary sources in the regions of the Republic of Bashkortostan]. Zdravookhranenie Rossiiskoi Federatsii, 2016, vol. 60, no. 4, pp. 192-198 (in Russian). DOI: 10.18821/0044-197X-2016-60-4-192-198

6. Dolgikh O.V., Predeina R.A., Dianova D.G. Experimental assessment of phenol influence on immunoregulation ex vivo. Health Risk Analysis, 2014, no. 1, pp. 83-87 (in Russian). DOI: 10.21668/health.risk/2014.1.10.eng

7. Review of the Environmental Protection Agency's Draft IRIS Assessment of Formaldehyde Purchase Options. Washington, D.C., The national academies press Publ., 2011, 194 p.

8. Zhai L., Zhao J., Xu B., Deng Y., Xu Z. Influence of indoor formaldehyde pollution on respiratory system health in the urban area of Shenyang, China. Afr. Health. Sci., 2013, no. 1, pp. 137-143. DOI: $10.4314 /$ ahs.v13i1.19 
9. Zinchenko N.A. Features of indoor air pollution. Zdorov'e i okruzhayushchaya sreda, 2013, no. 22, pp. 59-62 (in Russian).

10. Egorova V.N., Babachenko I.V., Degtyareva M.V., Popovich A.M. Interleikin-2: obobshchennyi opyt klinicheskogo primeneniya [Interleukin-2: synthesis of clinical experience]. Sankt-Peterburg, Ul'tra Print Publ., 2012, 98 p. (in Russian).

11. Poletaev A.B. Fiziologicheskaya immunologiya (estestvennye auto-antitela i problemy nanomeditsiny) [Physiological immunology (natural auto-antibodies and nanomedicine problems)]. Moscow, Miklosh Publ., 2011, 218 p. (in Russian).

12. Masnavieva L.B., Kudaeva I.V., Efimova N.V. The levels of specific autoantibodies and risks for the formation of pathological processes in conditions of inhalation exposure to chemicals. Gigiena $i$ sanitariya, 2015, vol. 94, no. 7, pp. 106-110 (in Russian).

13. Malek T.R. The biology of interleukin-2. Annual Review of Immunology, 2008, vol. 26, pp. 453-479. DOI: 10.1146/annurev.immunol.26.021607.090357

14. Gaffen S.L., Liu K.D. Overview of interleukin-2 function, production and clinical applications. Cytokine, 2004, vol. 28, no 3, pp. 109-123. DOI: 10.1016/j.cyto.2004.06.010

15. Granucci F., Andrews D.M., Degli-Esposti M.A., Ricciardi-Castagnoli P. IL-2 mediates adjuvant effect of dendritic cells. Trends Immunology, 2002, vol. 23, no. 4, pp. 169-171. DOI: $10.1016 / \mathrm{s} 1471-4906(02) 02187-7$

16. Yanagawa Y., Iwabuchi K., Onoé K. Co-operative action of interleukin-10 and interferongamma to regulate dendritic cell functions. Immunology, 2009, vol. 127, no. 3. pp. 345-353. DOI: $10.1111 / \mathrm{j} .1365-2567.2008 .02986 . x$

17. Sawitzki B., Kingsley C.I., Oliveira V., Karim M., Herber M., Wood K.J. IFN-gamma production by alloantigen-reactive regulatory $\mathrm{T}$ cells is important for their regulatory function in vivo. $J$. Exp. Med., 2005, vol. 201, no. 12, pp. 1925-1935. DOI: 10.1084/jem.20050419

18. Simbirtsev A.S. Tsitokiny: klassifikatsiya i biologicheskie funktsii [Cytokines: classification and biologic functions]. Tsitokiny $i$ vospalenie, 2004, vol. 3, no. 2, pp. 16-22 (in Russian).

19. Ozdemir C., Akdis M., Akdis C.A. T regulatory cells and their counterparts: masters of immune regulation. Clinical \& Experimental Allergy, 2009, vol. 39, no. 5, pp. 626-639.

20. Kudaeva I.V., Masnavieva L.B. The comparative analysis of immunological indicators in teenagers with different response to formaldehyde. Rossiiskii immunologicheskii zhurnal, 2015, vol. 9, no. 3, pp. 115-117 (in Russian).

21. Han R.T., Back S.K., Lee H., Lee J.H., Kim H., Kim H.J., Na H.S. Formaldehyde-Induced Aggravation of Pruritus and Dermatitis Is Associated with the Elevated Expression of Th1 Cytokines in a Rat Model of Atopic Dermatitis. PLoS One, 2016, vol. 11, no. 12, pp. e0168466. DOI: 10.1371/journal.pone.0168466

Masnavieva L.B., Kudaeva I.V. Influence exerted by inhalation burden with formaldehyde on cytokines level in teenagers living in industrial centers. Health Risk Analysis, 2020, no. 2, pp. 110-116. DOI: 10.21668/health.risk/2020.2.12.eng

Received: 05.12.2019

Accepted: 03.06.2020

Published: 30.06.2020 